\title{
COVID-19-associated acute necrotizing myelitis
}

Javier Sotoca, MD, and Yensa Rodríguez-Álvarez, MD

Neurol Neuroimmunol Neuroinflamm 2020;7:e803. doi:10.1212/NXI.0000000000000803

A 69-year-old otherwise healthy woman presented to our clinic with irradiated cervical pain, imbalance, and motor weakness and numbness in the left hand, which had been ongoing for 7 days. Eight days before the onset of these symptoms, she had fever and dry cough.

On admission, her neurologic examination showed right facial and left hand hypoesthesia, subtle left hand interosseous weakness, and general hyperreflexia.

MRI of the brain was normal, whereas spinal cord images (figure 1, A and D) showed T2hyperintensity extending from the medulla oblongata to $\mathrm{C} 7$, involving most of the cord with diffuse patchy enhancing lesions, suggesting acute transverse myelitis.

Extensive diagnostic workup was performed, showing negative results in blood test for infectious, autoimmune diseases (including myelin oligodendrocyte glycoprotein and aquaporin4 antibodies), and other potential causes such as vitamin deficits or antiphospholipid syndrome.

The patient's CSF analysis showed a traumatic puncture (75 erythrocytes $/ \mu \mathrm{L}$ ), mild lymphocytic pleocytosis ( 75 cells $/ \mu \mathrm{L}, 98 \%$ lymphocytes), hyperproteinorraquia of $2.83 \mathrm{~g} / \mathrm{L}$, normal adenosine deaminase, and glucose results; IgG index was normal, no oligoclonal bands were present, and bacterial culture and viral multi-PCR test were also negative. The presence of neuronal surface antibodies was also ruled out. Thoracoabdominal CT scan was negative for tumor and lymphadenopathy. SARS-CoV-2 PCR was positive in nasopharyngeal swab and negative in CSF. No cytokine levels were examined neither in serum nor CSF.

Treatment with methylprednisolone $1 \mathrm{~g}$ IV for 5 days resulted in initial improvement. However, a few days later, her clinical condition worsened markedly: she developed sensory motor deficits in both hands and paraparesis with sphincter incontinence.

A new spinal MRI was performed (figure 1, B and E), showing transversally and caudally progression until T6 level with similar enhancement and a new area of central necrosis at the T1 level with peripheral enhancement.

Treatment with plasma exchange and other course of methylprednisolone pulses for 5 days with posterior slow oral prednisone tapering resulted in improvement of strength and motor function, until being able to walk with assistance, use electronic devices such as typing on her mobile phone or write with some difficulties, remaining left leg moderate weakness and no sphincter control. After 4 weeks from the clinical onset, she continues improving slowly and performing physical and occupational therapy.

Spinal MRI postplasmapheresis (figure $1, \mathrm{C}$ and $\mathrm{F}$ ) showed substantial decrease in myelitis extension and enhancement, but central necrosis at the C7-T1 level remained unchanged.

Acute necrotizing myelitis (ANM) is a rare inflammatory disorder of the spinal cord. Only a few cases have been associated to inflammatory diseases such as neuromyelitis optica or vasculitis, paraneoplastic mechanisms, or adverse effect of new oncologic treatments. ${ }^{1-3}$
Correspondence

Dr. Sotoca

jsotoca@mutuaterrassa.cat

MORE ONLINE

COVID-19 Resources

For the latest articles, invited commentaries, and blogs from physicians around the world

NPub.org/COVID19 

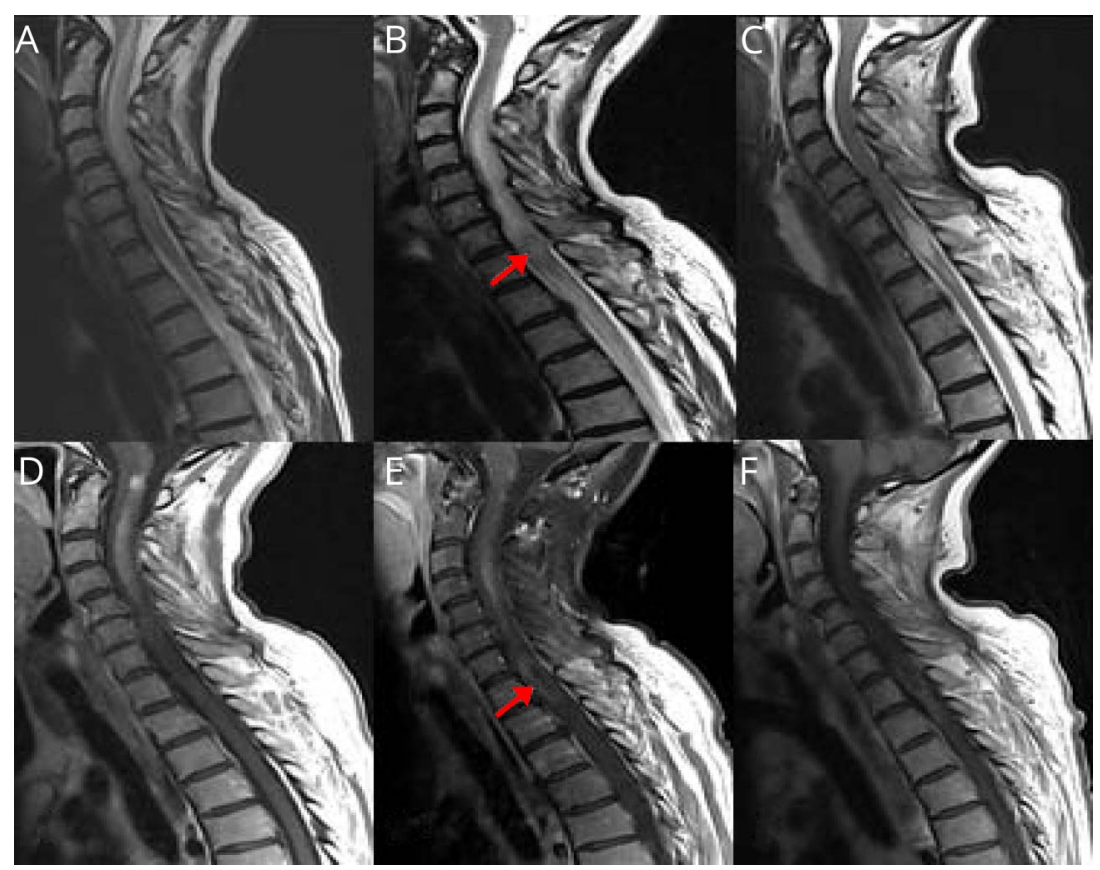

Sagittal T2-weighted (A-C) and sagittal postcontrast T1-weighted (D-F). Baseline performed (A and D), follow-up 1 week (B and $E$ ), and plasmapheresis posttreatment ( $C$ and $F$ ). A LETM is seen in the cervical spinal cord (A) with patchy enhancement (D). Progressive swelling of the spinal cord and a new necrotizing area (B: arrow) that shows peripheral enhancement (E: arrow). Significant decreases of both myelitis extension $(\mathrm{C})$ and enhancement $(\mathrm{F})$ after plasmapheresis treatment, with necrosis area in evolution. LETM = longitudinal extensive transverse myelitis.

Spine MRI in ANM usually shows hypointense T1 signal and corresponding increase in T2 signal and, characteristically, hemorrhage, cavitation, and postcontrast enhancement could also be seen.

The exact pathogenesis of ANM remains obscure, and analogously to acute necrotizing encephalitis (ANE), an inflammatory response ("cytokine storm") secondary to a viral infection has been postulated as a possible cause. ${ }^{4}$ Human coronaviruses are a group of respiratory viruses that can naturally reach the CNS in humans through hematogenous or neuronal retrograde route and could potentially be associated with neurologic symptoms. ${ }^{5}$ A systemic cytokine production due to the SARS-CoV-2 infection has been suggested to contribute to the pathophysiology of severe coronavirus disease 2019 (COVID-19). ${ }^{6}$ Recently, a case of ANE caused by the new coronavirus infection has been reported. ${ }^{7}$

In our patient, the presence of a longitudinal extensive transverse myelitis with subsequent worsening along with development of a necrotic area, associated with focal swelling, peripheral enhancement, and hypointense foci on T2 images, led us to the diagnosis of ANM in a patient COVID-19 positive. Immunomodulatory treatment such as steroids or plasmapheresis can result in neurologic improvement as the patient reported here.

Additional studies are needed to better define the potential role of human coronaviruses in the pathogenesis and the effectiveness of any therapeutic measure in the management of ANM.

\section{Acknowledgment}

The authors thank the patient and all the physicians and health personnel involved in the care of patients in the COVID-19 pandemic.

\section{Study funding}

Not related to this manuscript..

\section{Disclosure}

J. Sotoca reports no disclosures relevant to the manuscript. Y. Rodríguez-Álvarez reports no disclosures relevant to the manuscript. Go to Neurology.org/NN for full disclosures.

\section{Publication history}

Received by Neurology: Neuroimmunology \& Neuroinflammation May 11, 2020. Accepted in final form May 18, 2020.

Appendix Authors

\begin{tabular}{lll}
\hline Name & Location & Contribution \\
\hline $\begin{array}{l}\text { Javier } \\
\text { Sotoca, MD }\end{array}$ & $\begin{array}{l}\text { Neurology Department. } \\
\text { Hospital Universitari } \\
\text { MútuaTerrassa, Terrassa } \\
\text { (Barcelona), Spain }\end{array}$ & $\begin{array}{l}\text { Drafting and revising the } \\
\text { manuscript, data } \\
\text { acquisition, analysis and } \\
\text { interpretation of data, and } \\
\text { edited and approved the } \\
\text { final draft }\end{array}$ \\
$\begin{array}{l}\text { Yensa } \\
\text { Rodrígyez- } \\
\text { Álvarez, } \\
\text { MD }\end{array}$ & $\begin{array}{l}\text { Radiology Department. } \\
\text { Hospital Universitari }\end{array}$ & $\begin{array}{l}\text { Drafting and revising the } \\
\text { manuscript, edited }\end{array}$ \\
\hline
\end{tabular}




\section{References}

1. Katz JD, Ropper AH. Progressive necrotic myelopathy. Arch Neurol 2000;57: 355.

2. Okai AF, Muppidi S, Bagla R, Leist TP. Progressive necrotizing myelopathy: Part of the spectrum of neuromyelitis optica? Neurol Res 2006;28: 354-359.

3. Abdallah AO, Herlopian A, Ravilla R, et al. Ipilimumab-induced necrotic myelopathy in a patient with metastatic melanoma: a case report and review of literature. J Oncol Pharm Pract 2016;22:537-542.
4. Kansagra SM, Gallentine WB. Cytokine storm of acute necrotizing encephalopathy. Pediatr Neurol 2011;45:400-402.

5. Desforges M, Le Coupanec A, Dubeau P, et al. Human coronaviruses and other respiratory viruses: underestimated opportunistic pathogens of the central nervous system? Viruses 2019;12:1-28.

6. Moore JB, June CH. Cytokine release syndrome in severe COVID-19. Science 2020; 368:473-474.

7. Poyadji N, Shahin G, Noujaim D, et al. COVID-19 associated acute hemorrhagic necrotizing encephalopathy: CT and MRI features. Radiology 2020:201187. doi: $10.1148 /$ radiol.2020201187. 


\section{Neurology \\ Neuroimmunology \& Neuroinflammation}

COVID-19-associated acute necrotizing myelitis

Javier Sotoca and Yensa Rodríguez-Âlvarez

Neurol Neuroimmunol Neuroinflamm 2020;7;

DOI 10.1212/NXI.0000000000000803

This information is current as of June 10, 2020

Neurol Neuroimmunol Neuroinflamm is an official journal of the American Academy of Neurology.

Published since April 2014, it is an open-access, online-only, continuous publication journal. Copyright

Copyright $\odot 2020$ The Author(s). Published by Wolters Kluwer Health, Inc. on behalf of the American

Academy of Neurology.. All rights reserved. Online ISSN: 2332-7812.

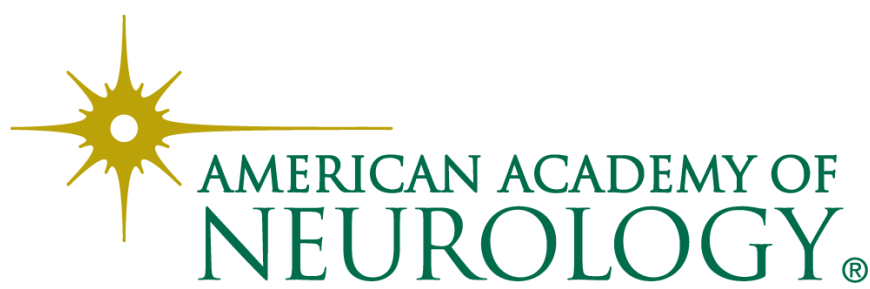




\section{Updated Information \& Services}

References

Citations

Subspecialty Collections

Permissions \& Licensing

Reprints including high resolution figures, can be found at: http://nn.neurology.org/content/7/5/e803.full.html

This article cites 7 articles, 1 of which you can access for free at: http://nn.neurology.org/content/7/5/e803.full.html\#\#ref-list-1

This article has been cited by 7 HighWire-hosted articles: http://nn.neurology.org/content/7/5/e803.full.html\#\#otherarticles

This article, along with others on similar topics, appears in the following collection(s):

All Demyelinating disease (CNS)

http://nn.neurology.org//cgi/collection/all_demyelinating_disease_cns All Spinal Cord

http://nn.neurology.org//cgi/collection/all_spinal_cord

\section{COVID-19}

http://nn.neurology.org//cgi/collection/covid_19

\section{MRI}

http://nn.neurology.org//cgi/collection/mri

Transverse myelitis

http://nn.neurology.org//cgi/collection/transverse_myelitis

Information about reproducing this article in parts (figures,tables) or in its entirety can be found online at:

http://nn.neurology.org/misc/about.xhtml\#permissions

Information about ordering reprints can be found online:

http://nn.neurology.org/misc/addir.xhtml\#reprintsus

Neurol Neuroimmunol Neuroinflamm is an official journal of the American Academy of Neurology.

Published since April 2014, it is an open-access, online-only, continuous publication journal. Copyright

Copyright $\odot 2020$ The Author(s). Published by Wolters Kluwer Health, Inc. on behalf of the American Academy of Neurology.. All rights reserved. Online ISSN: 2332-7812.

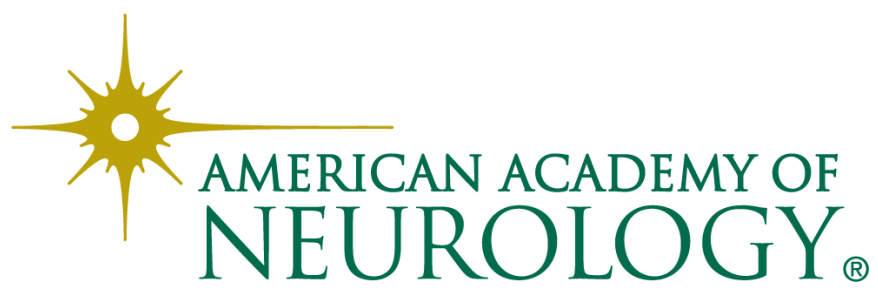

